Article

\title{
Government's Stimulus Program to Boost Consumer Spending: A Case of Discount Shopping Coupon Scheme in Japan
}

\author{
Yoshihiko Kadoya ${ }^{1}\left[\right.$, Mostafa Saidur Rahim Khan ${ }^{1, *(\mathbb{C})}$ and Tomomi Yamane ${ }^{2} \mathbb{C}$ \\ 1 School of Economics, Hiroshima University, 1-2-1 Kagamiyama, Higashi Hiroshima, Hiroshima 739-8525, \\ Japan; ykadoya@hiroshima-u.ac.jp \\ 2 Graduate School for International Development and Cooperation, Hiroshima University 1-5-1 Kagamiyama, \\ Higashi Hiroshima, Hiroshima 739-8529, Japan; tomomi@hiroshima-u.ac.jp \\ * Correspondence: khan@hiroshima-u.ac.jp
}

Received: 11 April 2020; Accepted: 9 May 2020; Published: 11 May 2020

\begin{abstract}
The unprecedented outbreak of COVID-19 has triggered a worldwide economic recession. Consequently, governments are pursuing different stimulus packages to alleviate the resulting pressures. This study examines one such program intended to enhance consumer spending during an economic downturn. In 2015, the Japanese government implemented a discount shopping coupon scheme, offering a $20 \%$ discount on purchases. This study aims to identify the groups of consumers who responded most to the discount shopping coupon scheme. To this end, we examine the demographic and socio-economic factors associated with the purchasers of discount shopping coupons in Hiroshima Prefecture, Japan. Using IV probit models, we show that middle-aged people, homemakers, household balance of financial assets, and short-term attitude are positively associated with the purchase of the coupons. Financial literacy reflects a negative association with the purchase of the coupons for respondents over the age of 40, whereas household income shows a positive association for middle-aged respondents. Our results imply that programs designed to improve consumer consumption may not be effective as blanket solutions that are applied to everyone indiscriminately, but rather seem to show efficiency when tailored to different people according to their demographic and/or socio-economic characteristics.
\end{abstract}

Keywords: consumer spending; discount shopping coupon; financial literacy; socio-economic factors; Japan

\section{Introduction}

To date, the world has been experiencing an unprecedented economic downturn due to the COVID-19 pandemic [1]. A significant number of economic activities have shut down, causing contractions in global output, as well as loss of businesses and family income. Recent evidence shows that nearly 3.3 million people in the United States have registered to claim jobless benefits for the week ended 21 March 2020 [2] and projecting the extent of the impending global economic loss remains a difficult endeavor. In response, numerous countries have implemented various economic stimulus programs to overcome this situation. With increasing unemployment, economists are devising and proposing economic measures that could help ensure a sustainable increase in consumer spending and circumvent a long-term economic recession. A discount shopping coupon scheme, for instance, is thought to be potentially effective in increasing consumer spending in countries where an economic downturn is projected. We studied the discount shopping coupon scheme implemented in Japan during a period of economic stagnation, after its economic bubble burst in 2000, to understand how this 
economic stimulus program could be helpful for other countries. Stiglitz [3] noted that Japan's economic stagnation was caused by supply and demand reductions, both in the real economy and the financial sector. Thus, to overcome the situation, Japan required effective policy initiatives to boost both supply and demand. Subsequently, in 2015, following a 0.001 percent drop in consumer spending (one of the contributing factors of the stagnation), the Japanese government implemented the scheme through local governments to boost consumer spending. Accordingly, 96\% of local governments issued discount shopping coupons as part of the central government-led Regional Consumption Stimulation and Life Support Program (Chiiki Shohi Kanki-Chiiki Shiengata Kofukin Jigyo). Decisions on the details of the implementation of this program were left to local governments so that the program could be tailored to fit the local context and be more sustainable. However, most local governments used a similar method. People who purchased these coupons were eligible for a $20 \%$ discount. For example, a coupon could be used to purchase products priced at JPY 1250 for JPY 1000. The discount coupon program generated immense interest as there were more applications than available coupons. According to the Cabinet Office's estimate [4], issuing discount shopping coupons stimulated an additional JPY 10.19 billion in spending. Hiroshima Prefecture announced that HIROCA led to an additional JPY 1.5 billion in local consumption. Some authors reported that these coupon programs had significant economic effects; however, neither their long-term effect nor their purchasing patterns were thoroughly investigated.

The use of coupons to boost regional and national sales is not a new policy measure; in fact, it has been used worldwide for many years. Kan et al. [5] studied the effect of a Taiwanese shopping coupon program on unplanned consumer spending and found that a $\$ 1$ increase in the shopping coupon value generated $\$ 0.24$ worth of unplanned spending. The Japanese government has circulated coupons to increase consumer spending on different occasions. For example, in March 1993, it distributed 31 million 'shopping coupons' worth JPY 20,000 each to the elderly and families with children. The terms of the coupon usage required that they be redeemed within six months and that they be used in the recipient's local community. Hsieh, Shimizutani, and Hori [6] studied the effect of these coupons on consumer spending and found that the program had a positive effect on spending on semi-durable products, but not on durables. Moreover, consumer spending did not fall after the coupons had been redeemed. The Japanese government used a similar program in 2009 when it distributed coupons worth JPY 12,000 each to every resident and an additional JPY 8000 to residents between the ages of 18 and 65. In addition to the national government, local authorities also provided purchase coupons with a fixed maturity date as an alternative to tax cuts.

Although there are a few studies that have examined how coupons affect users' purchase decisions, studies on whether these programs reach the target audience are scarce. Who the prime customers of these coupons are, their motivation to purchase such coupons, and why others do not purchase them, are still open questions that need to be understood to improve the effectiveness of these types of programs. Previous studies found that the relationship between coupon value and consumer spending was not always intuitively positive [7]. The relationship depended on factors such as price level, consumers' saving orientation, information-processing skill, and preexisting beliefs, among others. Thus, investigating consumers' profiles appears to be important for the success of discount coupons. Goto [8] studied the determinants of the purchase decision of discount shopping coupons, focusing on socio-economic determinants, and found that high-income households are more likely to purchase discount shopping coupons. Goto [8] used a Seijiyama Internet survey, which was conducted while consumers were making a purchase decision. The Seijiyama Internet survey included both actual and intended purchases of the coupons, thereby making socio-economic determinants of the discount shopping coupons usage less certain. Thus, there is still a need for a comprehensive study to clarify whether the shopping coupon scheme was directed at the right audience by examining consumers' shopping coupon purchase behavior. 
Government initiatives to boost production through stimulating consumer spending depend on the successful implementation of the proposed programs among the right consumer groups. As a result, understanding consumers' responses to stimulus programs is important. In light of this, this study's primary objective to identify the groups of consumers who responded most to the discount shopping coupon scheme. We hypothesize that peoples' socio-economic conditions determine whether they will respond to a government stimulus program such as the discount shopping coupon scheme. To this end, we examine the demographic and socio-economic factors associated with the purchasers of discount shopping coupons. The partial failure of the Japanese government in its earlier coupon schemes motivated us to conduct this study to provide evidence that an indiscriminate application of a stimulus program could be ineffective. Earlier the Japanese government introduced schemes to distribute free shopping coupons to the elderly, people of specific regions, and families with children. However, these schemes did not bring about long-term effects on consumer spending partly because the government did not target the right consumer groups. We argue that it is important to know which consumer groups need such stimulus and to design the stimulus program accordingly in order to have a long-term effect on consumer spending. To the best of our knowledge, no study has yet examined the demographic and socio-economic factors associated with the decision to purchase discount shopping coupons. Such an examination can help clarify whether the program effectively reached the right audience and provides evidence of consumers' spending behavior in terms of the consumer group that most frequently purchases discount coupons. Our research makes at least two contributions to the literature. First, this is the first study that examines the pattern and determinants of the usage of discount shopping coupons in Japan. Second, the findings of our research provide implications for the effectiveness of such programs during the economic situations projected to appear in the near future. Our study suggests that stimulus programs designed to improve consumer spending may not be effective as blanket solutions that are applied to everyone indiscriminately. The programs will be effective when governments effectively target the right consumer groups.

The rest of this paper is organized as follows. Data and methodology are presented in Section 2. Empirical results are outlined in Section 3, and finally, Section 4 provides the conclusions and limitations of the study.

\section{Data and Methodology}

\subsection{Data}

This study uses data on gender, age, and HIROCA purchases from HB's database. As the coupons were purchased through HIROCA, HB retained all relevant information. We collected other information through an internet survey conducted by Nikkei Research, Inc. from November 11 to December 12, 2017 in collaboration with HB.

A total of 3200 HIROCA purchasers were randomly selected to receive an online survey invitation with a target sample size of 250. A total of 12,634 non-HIROCA purchasers were selected to receive the invitation. The target sample size was 1226 . The response rate was $7.8 \%$ for HIROCA and $7.7 \%$ for non-HIROCA purchasers. Responses from 80 respondents did not match the original HB database and these were excluded from our analysis. Although we collected data only from the Hiroshima Prefecture because no other prefectures maintained a database for the discount shopping coupon scheme, we believe that the results of this study are not likely to be influenced if data from other prefectures were used. This is because consumers in most prefectures responded similarly to consumers from the Hiroshima Prefecture. Moreover, the Japanese are quite homogenous and are believed to have similar purchasing behavior throughout the nation.

Discount shopping coupons (DSC), which is a binary variable, is the dependent variable of this study whereas gender, age, age squared, schooling, financial literacy, homemaker, household size, household income, household balance of financial assets, and attitude towards future are the independent variables. Table 1 shows the variable definitions and their measurement. Table 2 shows the 
descriptive statistics of key variables. Results show that $21.39 \%(\mathrm{SD}=41.03 \%)$ respondents purchased the discount shopping coupon. The demographic features of the respondents indicate that $25.59 \%$ of respondents are females with an average age of 47.44 years ( $\mathrm{SD}=13.32$ years), have attained 15.12 years $(\mathrm{SD}=2.13)$ of education, scored $0.7335(\mathrm{SD}=0.3307)$ in financial literacy, and that $12.49 \%$ of them are homemakers. Socio-economic features of the respondents indicate that $68.27 \%$ live in urban areas, have a household size of almost three, a yearly household income of JPY 7215 thousand (SD = JPY 3953 thousand), and a household balance of financial assets of JPY 13,742 (SD = JPY 20,127 thousand). Respondents are also found to have a higher score on short-term attitude (mean $=0.7226$ and $\mathrm{SD}=0.4479)$.

Table 1. Definition of variables.

\begin{tabular}{|c|c|}
\hline \multicolumn{2}{|r|}{ Dependent Variables } \\
\hline DSC & $\begin{array}{l}\text { Discount shopping coupon. } 1=\text { purchased discount shopping } \\
\text { coupons, } 0=\text { otherwise }\end{array}$ \\
\hline \multicolumn{2}{|r|}{ Independent Variables } \\
\hline Female & Gender of respondent \\
\hline Age & Age in years \\
\hline Age_sq & Age squared \\
\hline Schooling & Years of schooling \\
\hline \multirow{4}{*}{ Fin_lit } & $\begin{array}{l}\text { Financial literacy. Financial literacy is measured by respondents' } \\
\text { ability to answer the following questions: }\end{array}$ \\
\hline & $\begin{array}{l}\text { 1. "With high inflation, the price of goods and services used } \\
\text { in daily life will rapidly rise." True or False }\end{array}$ \\
\hline & $\begin{array}{l}\text { 2. "Investments with a higher return than average have } \\
\text { a higher than average risk." True or False }\end{array}$ \\
\hline & $\begin{array}{l}\text { 3. "It is a safer investment to buy stock of one company than } \\
\text { to buy a stock investment trust." True or False }\end{array}$ \\
\hline Homemaker & $1=$ married female who is not working, $0=$ otherwise \\
\hline Region_urban & $\begin{array}{l}1 \text { if living in one of two major cities in Hiroshima Prefecture: } \\
\text { Hiroshima city and Fukuyama city, } 0=\text { otherwise }\end{array}$ \\
\hline HH_size & Number of household members \\
\hline HH_income & Household income (10 thousand JPY) \\
\hline Assets_financial & Household balance of financial assets (10 thousand JPY) \\
\hline Attitude_short-term & $\begin{array}{l}\text { Measured by two questions related to attitude toward the future } \\
\text { I find it more satisfying to spend than to save for the long term } \\
\text { I tend to live for today and let tomorrow take care of itself }\end{array}$ \\
\hline Japanese_good (IV) & $\begin{array}{l}1=\text { respondents' self-claim that their Japanese grade at high } \\
\text { school was very good or good, } 0=\text { otherwise }\end{array}$ \\
\hline
\end{tabular}


Table 2. Descriptive statistics.

\begin{tabular}{cccccc}
\hline Variable & Obs & Mean & Std. Dev. & Min & Max \\
\hline DSC & 977 & 0.2139 & 0.4103 & 0 & 1 \\
Female & 977 & 0.2559 & 0.4366 & 0 & 1 \\
Age & 977 & 47.4422 & 13.3216 & 21 & 94 \\
Schooling & 977 & 15.1233 & 2.1253 & 9 & 21 \\
Fin_lit & 977 & 0.7335 & 0.3307 & 0 & 1 \\
Homemaker & 977 & 0.1249 & 0.3307 & 0 & 1 \\
Region_urban & 977 & 0.6827 & 0.4657 & 0 & 1 \\
HH_size & 977 & 2.8649 & 1.3167 & 1 & 9 \\
HH_income & 977 & 721.5455 & 395.2769 & 50 & 2000 \\
Assets_financial & 977 & 1374.2320 & 2012.7510 & 125 & 10,000 \\
Attitude_short-term & 977 & 0.7226 & 0.4479 & 0 & 1 \\
\hline
\end{tabular}

Table 3 shows the percentage of coupon purchasers based on selected demographic and socio-economic variables. Results show that $18.02 \%$ are male and $31.20 \%$ female; $16.78 \%$ are younger than 40 years old, $24.71 \%$ are between 40 and 65 years, and $14.13 \%$ are older than 65 years. It also shows that $45.08 \%$ are homemakers; $25.00 \%$ have less than 12 years of education, $21.95 \%$ have 12 to 16 years of education, and $16.81 \%$ have more than 16 years of education. In terms of financial literacy, $18.35 \%$ score less than 0.50 and $22.27 \%$ score more than 0.50 . Of the respondents, $21.46 \%$ were employed at the time of the survey and $20.87 \%$ were not. In addition, $18.99 \%$ of respondents had less than average yearly income at the time, while $26.23 \%$ of respondents had above-average income; $17.83 \%$ of respondents had a less than average balance of financial assets, while $31.85 \%$ of respondents had an above-average balance. Results show that respondents who are female, middle aged, homemakers, have an education of less than 16 years, currently employed, and have above-average income and assets, purchased more discount shopping coupons than their peers.

Table 3. Purchase of discount shopping coupons based on selected variables.

\begin{tabular}{cc}
\hline Variables & DSC \\
\hline Gender & $18.02 \%$ \\
Male & $31.20 \%$ \\
\hline Female & \\
\hline Age (years) & $16.78 \%$ \\
\hline$<40$ & $24.71 \%$ \\
$40-65$ & $14.13 \%$ \\
$>65$ & \\
\hline Homemaker & $45.08 \%$ \\
\hline Yes & $18.01 \%$ \\
\hline No & \\
\hline Education (years) & $25.00 \%$ \\
\hline$<12$ & $21.95 \%$ \\
$12-16$ & $16.81 \%$ \\
\hline$>16$ & \\
\hline Financial Literacy & $18.35 \%$ \\
\hline$<0.50$ & $22.27 \%$ \\
\hline$>0.50$ & $21.46 \%$ \\
\hline Employment & $20.87 \%$ \\
\hline Employed & \\
\hline Unemployed & \\
\hline
\end{tabular}


Table 3. Cont.

\begin{tabular}{cc}
\hline Variables & DSC \\
\hline Household Income (thousand JPY) & \\
\hline$<7210$ & $18.99 \%$ \\
$>7210$ & $26.23 \%$ \\
\hline Household balance of financial assets (thousand JPY) \\
\hline$<13,740$ & $17.83 \%$ \\
$>13,740$ & $31.85 \%$ \\
\hline
\end{tabular}

\subsection{Methods}

We used an IV probit regression model to examine how demographic and socio-economic factors are associated with the purchase of discount shopping coupons. Because the dependent variable, whether respondents purchase discount shopping coupons, is a binary variable, a probit regression model would be the best model for our study. The independent variables include financial literacy, gender, age, age_squared, education, homemaker, region, attitude, household size, household income, and household balance of financial assets. Given the endogenous nature of financial literacy, we controlled endogeneity using an instrument called Japanese language ability. Japanese language ability, which has been proxied by respondents' performance on Japanese language in the school level, is related to financial literacy but apparently does not influence the decision to purchase discount shopping coupon. The relevance of the Japanese language ability with financial literacy has been evident in previous literature as well [9]. In an unreported analysis, we estimated the relationship between Japanese language ability and financial literacy and found the relationship to be significantly positive. The general form of the equation is as follows:

$$
\begin{aligned}
\text { purchase of DSC } & (1=\text { purchased, and } 0 \text { otherwise }) \\
& =\alpha+\beta_{1}\left(\text { fin }_{\text {lit }}=J a p a n e s e \_g o o d\right)+\beta_{2} f e m a l e+\beta_{3} a g e+\beta_{4} a g e \_s q+\beta_{5} \text { schooling } \\
& +\beta_{6} \text { homemaker }+\beta_{7} \text { region_urban }+\beta_{8} H H \_s i z e+\beta_{9} H H \_i n c o m e \\
& +\beta_{10} \text { assets_financial }+\beta_{11} \text { attitude_short term }+e_{i}
\end{aligned}
$$

\section{Empirical Results and Discussion}

We constructed several regression models to understand how demographic and socio-economic factors are associated with the purchasers of discount shopping coupons. Model 1 of Table 4 shows the results of the probit regression model when financial literacy is not instrumented. Financial literacy appears to be significantly positively related to the usage of discount shopping coupons. Previous studies also provide supportive evidence on how financial literacy influences economic and financial decisions [9-15]. Among other variables, age is positively related to discount shopping coupons; however, at the same time, the coefficient of age_squared is significantly negative, indicating that age is not linearly related to the purchase of such coupons. The age coefficient suggests that middle-aged people are the prime customers of the coupons. Homemaker, as a variable, is also found to be positively related to discount shopping coupons, as is the household balance of financial assets. 
Table 4. Estimation results.

\begin{tabular}{cccc}
\hline \multicolumn{2}{c}{ Model 1 (Probit Model) } & \multicolumn{2}{c}{ Model 2 (IV Probit Model) } \\
\hline Fin_lit & $0.2836(1.83)^{*}$ & Fin_lit & $-1.2731(-0.81)$ \\
Female & $0.1818(1.19)$ & Female & $0.0195(0.08)$ \\
Age & $0.0989(3.55)^{* * *}$ & Age & $0.0962(3.19)^{* * *}$ \\
Age_sq & $-0.0010(-3.58)^{* * *}$ & Age_sq & $-0.0010(-2.97)^{* * *}$ \\
Schooling & $-0.0246(-1.03)$ & Schooling & $0.0110(0.25)$ \\
Homemaker & $0.6150(3.33)^{* * *}$ & Homemaker & $0.4827(1.76)^{*}$ \\
Region_urban & $-0.1458(-1.46)$ & Region_urban & $-0.1380(-1.42)$ \\
HH_size & $0.0162(0.41)$ & HH_size & $-0.0017(-0.04)$ \\
HH_income & $0.0001(0.54)$ & HH_income & $0.0001(1.02)$ \\
Assets_financial & $0.0001(2.85)^{* * *}$ & Assets_financial & $0.0001(3.50)^{* * *}$ \\
Attitude_short-term & $0.1786(1.41)$ & Attitude_short-term & $0.3532(1.87)^{*}$ \\
_cons & $-3.2283(-4.16)^{* * *}$ & -cons & $-2.5996(-2.05)^{* *}$ \\
\hline Obs. & 977 & Obs. & 977 \\
LR chi2 & $81.72^{* * *}$ & Wald chi2 & $95.59 * * *$ \\
Pseudo R2 & 0.0806 & & -708.1197 \\
Log likelihood & -466.3039 & Log likelihood & \\
\hline
\end{tabular}

Note: $z$ statistics in parentheses. ${ }^{* * *}, * *$, and ${ }^{*}$ represent significance at the 1 percent, 5 percent, and 10 percent levels, respectively.

Previous studies revealed that financial literacy is endogenous in nature when explaining investment in stock markets, wealth accumulation, and retirement planning, among others $[11-13,15,16]$. As a result, it is also likely that financial literacy is endogenous in its relationship with discount shopping coupons. We again controlled for this endogeneity using the Japanese language ability instrument variable. Model 2 of Table 4 provides the empirical results of the IV probit regression model. The results show that financial literacy is no longer significantly related to the purchase of discount shopping coupons. The coefficients of age is positive and the squared term is negative at the $1 \%$ level, suggesting that the probabilities of purchasing discount shopping coupons peak in the middle of the age range. In other words, the results suggest that middle-aged people purchased the most coupons, which seems to be logical because respondents of this age group are more likely to be active income earners that are responsible for family spending. Homemaker, household balance of financial assets, and short-term attitude are also found to be positively related to the purchase of discount shopping coupons. The result seems logical because homemakers usually shop for the family and can spend time purchasing coupons. Other variables such as gender, schooling, region, attitude, household size, household income, and attitude are not found to be related to the purchase of discount shopping coupons.

The coefficients of age and age_squared suggest that we need to examine the effect of age on the purchase of discount shopping coupons in more depth. The reason for an inverse U-shaped usage curve could be the income capacity and employment status of the users. As respondents of the younger and older age groups are more likely to have less income than the middle-age groups, they are less likely to purchase discount shopping coupons. The middle-aged group is also more likely to have stable employment than the other two groups and be the functional head of the family, requiring them to manage the family expenditure in the most effective way. As a result, middle-aged respondents are more likely to buy discount shopping coupons. Previous studies also support that people's income increases with age but decreases after a certain age [17]. Foster [17] also reported that annual consumer expenditure was hump-shaped: lowest for younger groups, increasing for the middle-aged group, and then declining for older groups.

Given the inverse U-shaped age curve in the purchase of discount shopping coupons, we created subsamples of respondents aged less than 40 years, between 40 and 65 years, and more than 65 years to understand the relationship between discount shopping coupons and other variables more intuitively. We created these sub-samples because previous studies have found that respondents aged between 40 and 65 are more concerned about family, respondents aged over 65 are retired and respondents below 
40 years include non-earning members of the family [18]. Table 5 shows the results of the IV probit regression coefficients for the age-based sub-samples. Models 1, 2, and 3 show regression coefficients for respondents younger than 40 years, between 40 years and 65 years, and older than 65 years, respectively. The results of Model 1 show that the homemaker and household balance of financial assets variables are positively related to the purchase of discount shopping coupons. The results of Model 2 show that the relationships between discount shopping coupons and income, assets, and short-term attitude are significant for those aged between 40 and 65, suggesting that wealthy people who are more prone to current consumption purchased the coupons. However, being a homemaker, which was a significant factor for the whole sample, is not found to influence the coupon purchase decision. Instead, financial literacy is found to be negatively related to the purchase of discount shopping coupons. It seems that financially literate people are more likely to save and accumulate assets for the future rather than for current consumption. Previous studies also found that financially literate people accumulate assets through savings and investment $[9,19]$. Finally, Model 3, which represents the respondents older than 65 years of age, shows that financial literacy and schooling are, respectively, negatively and positively related to the purchase of discount shopping coupons. Like middle-aged respondents, older respondents who are financially literate prefer not to purchase discount shopping coupons. Variables such as household income, balance of financial assets, homemakers, and short-term attitude do not influence the purchase decision of discount shopping coupons. These results indicate that older respondents did not make significant purchases of the discount coupons. Their behavior is consistent with the findings of previous studies, which reported a fall in consumption around the retirement age [20].

Table 5. Estimation results of age-based sub-samples.

\begin{tabular}{|c|c|c|c|c|c|}
\hline \multicolumn{2}{|c|}{ Model 1 (Age: <40 Years) } & \multicolumn{2}{|c|}{ Model 2 (Age: 40 to 65 Years) } & \multicolumn{2}{|c|}{ Model 3 (Age: >65 Years) } \\
\hline Fin_lit & $0.7626(0.47)$ & Fin_lit & $\begin{array}{l}-2.7963 \\
(-2.45)^{* *}\end{array}$ & Fin_lit & $\begin{array}{c}-3.8303 \\
(-2.86)^{* * *}\end{array}$ \\
\hline Female & $-0.1884(-0.48)$ & Female & $0.0313(0.11)$ & Female & $0.1085(0.22)$ \\
\hline Schooling & $-0.0736(-1.20)$ & Schooling & $0.0529(1.35)$ & Schooling & $0.1582(2.68)^{* * *}$ \\
\hline Homemaker & $0.6953(2.20)^{* *}$ & Homemaker & $0.1503(0.29)$ & Homemaker & $0.0000(0.00)$ \\
\hline Region_urban & $-0.0997(-0.47)$ & Region_urban & $-0.1812(-1.47)$ & Region_urban & $0.2034(0.83)$ \\
\hline HH_size & $0.0906(1.18)$ & HH_size & $-0.0222(-0.59)$ & HH_size & $-0.1990(-0.79)$ \\
\hline HH_income & $0.0000(0.09)$ & HH_income & $0.0003(2.17)^{* *}$ & HH_income & $0.0001(0.19)$ \\
\hline Assets_financial & $0.0003(3.15)^{* * *}$ & Assets_financial & $0.0001(2.11)^{* *}$ & Assets_financial & $0.0001(0.58)$ \\
\hline Attitude_short-term & $0.2950(0.76)$ & Attitude_short-term & $0.4020(2.66)^{* * *}$ & Attitude_short-term & $0.0632(0.10)$ \\
\hline _cons & $\begin{array}{c}-0.98924 \\
(-0.82)\end{array}$ & _cons & $0.5306(0.56)$ & _cons & $0.7322(0.26)$ \\
\hline Obs. & 286 & Obs. & 599 & Obs. & 90 \\
\hline Wald chi2 & $25.78^{* * *}$ & Wald chi2 & $228.53^{* * *}$ & Wald chi2 & $65.62^{* * *}$ \\
\hline Log likelihood & -197.3938 & Log likelihood & -451.4181 & Log likelihood & -31.1983 \\
\hline
\end{tabular}

The significant positive association between the homemaker variable and the purchase of discount shopping coupons is an important finding. In our study, homemakers are those who are married but not engaged in any job. There could be several explanations for why homemakers appear to be the significant purchasers of discount shopping coupons. First, homemakers are generally in charge of household purchases and need to manage the household budget. As a result, homemakers are more likely to purchase these coupons to save on household expenditure. Second, our study does not include any other variable to represent the employment status of the respondents. Thus, the result could indicate that discount shopping coupons are attractive to unemployed people. Third, there was a higher demand for discount shopping coupons than the intended supply. As a result, prospective buyers had to spend a lot of time waiting in queues to purchase the coupons. Homemakers, not being engaged in any job, had lower opportunity cost and thus, were in a better position to obtain the coupons than the other respondents.

To understand how age, region, household income, and balance of financial assets play a role in the purchase of discount shopping coupons, we used several interaction terms in addition to the 
original variables. Table 6 shows IV logit regression coefficients of the original variables and interaction terms. The significance of the homemaker variable disappears after including interaction terms in the model and none of the interaction terms are found to be significant. The results suggest that there is no specific pattern of significance in the homemaker variables' influence on the purchase of discount shopping coupons, contrary to what was found in the original model. The influence of age, region, balance of financial assets, and short-term attitude on the purchase of discount shopping coupons remains the same.

Table 6. Estimation results including interaction terms.

\begin{tabular}{cc}
\hline Variables & Coefficients \\
\hline Fin_lit & $-1.2711(-0.85)$ \\
Female & $0.0200(0.09)$ \\
Age & $0.0905(2.96)^{* * *}$ \\
Age_sq & $-0.0009(-2.82)^{* * *}$ \\
Schooling & $0.0088(0.21)$ \\
Homemaker & $-0.2978(-0.45)$ \\
Region_urban & $-0.2069(-1.93)^{*}$ \\
HH_size & $-0.0013(-0.03)$ \\
HH_income & $0.0002(1.17)$ \\
Assets_financial & $0.0001(3.03)^{* * *}$ \\
Attitude_short-term & $0.3652(1.92)^{*}$ \\
Homemakerxage & $0.0139(1.07)$ \\
Homemakerxregion & $0.4788(1.64)$ \\
Homemakerxincome & $-0.0004(-0.80)$ \\
Homemakerxassets & $0.0001(0.85)$ \\
_cons & $-2.3992(-1.96)^{* *}$ \\
Obs. & 977 \\
Wald chi2 & $99.71 * *$ \\
Log likelihood & -701.6949 \\
\hline
\end{tabular}

Note: $z$ statistics in parentheses. ${ }^{* * *}, * *$ and ${ }^{*}$ represent significance at the 1 percent, 5 percent, and 10 percent levels, respectively.

Household balance of financial assets increases the probability of purchasing discount shopping coupons. The relationship is significant for the whole sample and most of the sub-samples. The relationship is rational because the balance of financial assets comprises a major portion of the total assets and indicates the financial soundness of respondents. Previous studies also found that consumer spending was higher for wealthy consumers [21]. Thus, it is more likely that financially solvent people will purchase discount shopping coupons.

Finally, having a current consumption spree increases the probability of purchasing discount shopping coupons. A short-term attitude indicates that respondents place more emphasis on current consumption than on future savings. A positive coefficient indicates that those who emphasize current consumption compared to future savings are more likely to purchase discount shopping coupons. Jia et al. [7] also argued that the trade-off between current consumption and future savings determined consumer spending using discount coupons.

Broadly, consumers who need to maintain families, can afford it financially and are currently on a consumption spree responded positively to the discount shopping coupon scheme, which supports our hypothesis that peoples' socio-economic conditions determine whether they will respond to the discount shopping coupon scheme. This study's results imply that for some socio-economic reasons consumers responded to a particular type of stimulus program more enthusiastically and make the program effective. We argue that each stimulus program has its own beneficiary groups and modes of distribution, which governments must understand before implementing the program. Because of the projected economic downturn caused by the COVID-19 health pandemic, governments of most of the countries are on the verge of declaring stimulus programs. If the stimulus programs do not reach their 
beneficiary groups in the right modes, either the program will be underutilized, or it will drain money to unintended places and result in an inefficient allocation of resources.

\section{Conclusions}

The emergence of the COVID-19 health pandemic has put the world economy into a recession. Effective government stimulus packages are needed to overcome the situation. To understand the effectiveness of one such government stimulus program, this study examined the profile of purchasers of discount shopping coupons issued by the Japanese government in 2015 . A total of $96 \%$ of all local governments issued discount shopping coupons as part of the central government-led Regional Consumption Stimulate and Life Support Program to boost consumer spending. The discount shopping coupons allowed consumers a $20 \%$ discount on purchases. We used Hiroshima Prefecture as our study sample as no other prefecture has maintained a database of the purchase of coupons. Discount shopping coupons were purchased through HB's HIROCA e-money scheme, and the bank maintained all necessary information on the usage of HIROCA, which we used in this study.

This study's primary objective is to identify the groups of consumers who responded mostly to the discount shopping coupon scheme. We hypothesize that peoples' socio-economic conditions determine whether they will respond to a government stimulus program such as the discount shopping coupon scheme. To investigate this research problem, we examine the demographic and socio-economic factors associated with the purchasers of discount shopping coupons. Results show that respondents who are female, middle-aged, homemakers, with an education of less than 16 years, and an above-average income and assets purchased more discount shopping coupons. Coefficients of the IV probit model indicate that age has a positive but non-linear relationship with the purchase of discount shopping coupons, indicating that middle-aged people are most likely to buy discount shopping coupons. Homemakers, defined as married women who are currently not employed, are also more likely to purchase discount shopping coupons. Having a greater household balance of financial assets also increases the probability of purchasing such coupons. Finally, respondents who emphasize current consumption more than saving for the future tend to purchase discount shopping coupons more. Education, financial literacy, household size, and household income are not associated with the purchase of discount shopping coupons. However, when the whole sample is grouped based on age, financial literacy is found to be negatively associated with the purchase of discount shopping coupons for respondents over 40 years of age. Household income is also found to be positively associated with the purchase of discount shopping coupons for middle-income respondents. Overall, consumers who need to maintain families, can afford it financially and are currently on a consumption spree responded positively to the discount shopping coupon scheme. These results imply that for some socio-economic reasons consumers responded to a particular type of stimulus program more enthusiastically and make the program effective. We argue that programs designed to improve consumer consumption may not be effective as blanket solutions that are applied to everyone indiscriminately, but rather seem to show efficiency when tailored to different people according to their demographic and/or socio-economic characteristics. However, it is still not conclusive whether the immediate benefits created by the stimulus programs are sustainable in the long run. Thus, future research should be targeted to investigate the long-term influence of stimulus programs on their desired economic outcomes.

Although our research makes important contributions to the literature, it has some limitations that should be considered when interpreting the results. First, there is a two-year gap between the policy implementation and the survey; discount shopping coupons were issued in 2015, but the survey took place in 2017. Thus, demographic and socio-economic backgrounds of the respondents could have changed to some degree. Second, we only considered the purchase of discount shopping coupons through HIROCA but not coupons issued separately by municipalities in Hiroshima Prefecture. Third, the survey was collected only from HB's Value One members to whom HB issued credit cards. Only $6.58 \%$ of HIROCA purchasers were members of the Value One program. 
Nonetheless, empirical evidence from this study will add value given the current lack of research on the effectiveness of this kind of economic policy. Our results suggest that government initiatives to support consumer spending at household level boost consumer demand. Thus, policymakers should consider formulating stimulus programs that target particular groups at household level as a means to effectively overcome future economic downturn.

Author Contributions: Conceptualization, Y.K. and T.Y.; methodology, Y.K., M.S.R.K. and T.Y.; software, Y.K., M.S.R.K. and T.Y.; validation, Y.K. and M.S.R.K.; formal analysis, Y.K., M.S.R.K. and T.Y.; investigation, Y.K., M.S.R.K., and T.Y.; resources, Y.K.; data curation, Y.K. and T.Y.; writing—original draft preparation, Y.K., M.S.R.K., and T.Y.; writing - review and editing, Y.K., M.S.R.K. and T.Y.; visualization, Y.K. and M.S.R.K.; supervision, Y.K.; project administration, Y.K.; funding acquisition, Y.K. All authors have read and agreed to the published version of the manuscript.

Funding: This research was funded by JSPS KAKENHI Grant Numbers JP15KK0083, JP15K17075, 19K13739, 19K13684; and RISTEX, JST.

Acknowledgments: The authors are deeply grateful to Atsuhito Uemaru, Tatsuya Hasegawa, Satoru Kubota, Eiichi Kuramoto, Kotaro Endo, and Keiya Ogura for their kind supports in data collection.

Conflicts of Interest: The authors declare no conflict of interest.

\section{References}

1. International Monetary Fund. The IMF and COVID-19 (Coronavirus). Available online: https://www.imf. org/en/Topics/imf-and-covid19 (accessed on 28 March 2020).

2. BBC News. Coronavirus: Record Number of Americans File for Unemployment. Available online: https: //www.bbc.com/news/business-52050426 (accessed on 28 March 2020).

3. Stiglitz, J.E.; Columbia Business School. A Better Economic Plan for Japan. Shazen Global Insights [Online]. 20 September 2016. Available online: https://www8.gsb.columbia.edu/articles/chazen-global-insights/bettereconomic-plan-japan (accessed on 17 July 2018).

4. Cabinet Office. Report on the Evaluation of the Regional Consumption Stimulate and Life Support Program (Regional Consumption Stimulate and Life Support Program). Available online: https:/www.kantei.go.jp/jp/ singi/sousei/pdf/kouhukin-hokoku.pdf (accessed on 17 July 2018).

5. Kan, K.; Peng, S.-K.; Wang, P. Understanding consumption behavior: Evidence from consumers' reaction to shopping coupons. Am. Econ. J. Econ. Policy 2017, 9, 1-18.

6. Hsieh, C.-T.; Shimizutani, S.; Hori, M. Did Japan's shopping coupon program increase spending? J. Public Econ. 2010, 94, 523-529.

7. Jia, H.; Yang, S.; Lu, X.; Park, C.W. Do consumers always spend more when coupon face value is higher? The inverted U-shaped effect of coupon face value on consumer spending level. J. Mark. 2018, 82, 70-85.

8. Goto, A. Premium shohinken no keizaikoudou (Economic determinants of discount shopping coupons: Focusing on socio-economic factors for purchase decision). J. Behav. Econ. Finance 2015, 8, 86-89.

9. Sekita, S. Financial Literacy and Wealth Accumulation: Evidence from Japan; Discussion Paper, No. 2013-01; Graduate School of Economics, Kyoto Sangyo University: Kyoto, Japan, 2013.

10. Cheng, Y.-F.; Mutuc, E.B.; Tsai, F.-S.; Lu, K.-H.; Lin, C.-H. Social capital and stock market participation via technologies: The role of households' risk attitude and cognitive ability. Sustainability 2018, 10, 1904. [CrossRef]

11. Kadoya, Y.; Khan, M.S.R. Can financial literacy reduce anxiety about life in old age? J. Risk Res. 2018, 21, 1533-1550. [CrossRef]

12. Kadoya, Y.; Khan, M.S.R.; Hamada, T.; Dominguez, A. Financial literacy and anxiety about life in old age: Evidence from the USA. Rev. Econ. Househ. 2018, 16, 859-878. [CrossRef]

13. Kadoya, Y.; Khan, M.S.R.; Oba, H.; Narumoto, J. Factors affecting knowledge about the adult guardianship and civil trust systems: Evidence from Japan. J. Women Aging 2020. [CrossRef] [PubMed]

14. Swiecka, B.; Yeşildağ, E.; Özen, E.; Grima, S. Financial literacy: The case of Poland. Sustainability 2020, 12, 700. [CrossRef]

15. Van Rooij, M.C.J.; Lusardi, A.; Alessie, R.J.M. Financial literacy and stock market participation. J. Financ. Econ. 2011, 101, 449-472. [CrossRef] 
16. Watanapongvanich, S.; Binnagan, P.; Putthinum, P.; Khan, M.S.R.; Kadoya, Y. Financial Literacy and Gambling Behavior: Evidence from Japan. J. Gambl. Stud. 2020. [CrossRef] [PubMed]

17. Foster, A.C. Consumer Expenditures Vary by Age. Beyond the Numbers: Prices \& Spending. U.S. Bureau of Labor Statistics, 4 December 2015. Available online: https://www.bls.gov/opub/btn/volume-4/consumerexpenditures-vary-by-age.htm (accessed on 17 July 2018).

18. Kadoya, Y. What makes people anxious about life after the age of 65? Evidence from international survey research in Japan, the United States, China, and India. Rev. Econ. Househ. 2016, 14, 443-461. [CrossRef]

19. Van Rooij, M.C.J.; Lusardi, A.; Alessie, R.J.M. Financial literacy, retirement planning and household wealth. Econ. J. 2012, 122, 449-478. [CrossRef]

20. Banks, J.; Blundell, R.; Tanner, S. Is there a retirement-savings puzzle? Am. Econ. Rev. 1998, 88, 769-788.

21. Doms, M. What Drives Consumer Spending? Economics and Statistics Administration. Available online: http://www.esa.doc.gov/under-secretary-blog/what-drives-consumer-spending (accessed on 16 July 2018).

(C) 2020 by the authors. Licensee MDPI, Basel, Switzerland. This article is an open access article distributed under the terms and conditions of the Creative Commons Attribution (CC BY) license (http://creativecommons.org/licenses/by/4.0/). 